\title{
Microstructures and K-Ar illite fine-fraction ages of the cataclastic rocks associated to the Camburu Shear Zone, Ribeira Belt, Southeastern Brazil
}

\author{
Microestruturas e idades $K$-Ar em ilitas de frações finas das rochas \\ cataclásticas associadas à Zona de Cisalhamento Camburu, Faixa \\ Ribeira, sudeste do Brasil
}

\author{
Claudio Alejandro Salazar Mora ${ }^{1 *}$, Ginaldo Ademar da Cruz Campanha ${ }^{1}$, \\ Klaus Wemmer ${ }^{2}$
}

\begin{abstract}
The Camburu Shear Zone (CSZ) is recognized as a NE-SW trending dextral transcurrent fault and is related to the evolution of the Ribeira Belt, southeastern Brazil. The CSZ ductile regime dates from the Precambrian to the Cambro-Ordovician and it is characterized by a meter to hundreds of meters wide belt of quarzto-feldspathic mylonitic rocks organized in a positive-flower structure. Previous studies postulated that the fault underwent normal reactivation, probably during the Cenozoic, developing metric to centimetric thick intercalations of cemented cataclastic rocks. We concluded that these cataclastic rocks maintained their primary cohesion and were syntectonically silicified by feldspar-to-mica reactions. Cataclasis was shown by the fractal distribution of grains and fragments, dilatancy, rigid body rotation, cataclastic flow, microcracking and microfaulting. Two cataclastic events are described: (i) during the Lower Devonian $(402 \pm 6 \mathrm{Ma})$ in a ductile-to-brittle regime with temperatures up to $400^{\circ} \mathrm{C}$ and development of foliated protocataclasites, and (ii) during the Upper Carboniferous $(310.9 \pm 8 \mathrm{Ma})$ in a brittle regime with temperatures up to $-300^{\circ} \mathrm{C}$ and development of protocataclasites and crushed breccias. It is then suggested that the CSZ cataclasites were formed during two Paleozoic reactivation events associated to a far-field orogenic effect induced by the Precordillera and Chanica orogenic cycles in the western margin of the Gondwana Paleocontinent. KEYWORDS: cataclasites; microstructures; fault rocks; K-Ar illite fine-fraction ages.
\end{abstract}

\begin{abstract}
RESUMO: A Zona de Cisalbamento Camburu (ZCC) apresenta direção NE-SW com movimentação lateral destral e está associada à evolução da Faixa Ribeira, no SE brasileiro. O regime dúctil da ZCC evoluiu desde o Pré-Cambriano até o Cambro-Ordoviciano, desenvolvendo faixas espessas $(-100 \mathrm{~m})$ de rochas miloniticas quartzo-feldspáticas. Trabalhos anteriores sugerem reativaçôes Cenozóicas de caráter normal com a geração de faixas métricas de rochas cataclásticas cimentadas. Neste trabalho, concluimos que tais cataclasitos mantiveram sua coesão primária e foram silicificados por reaçöes sin-tectônicas. A cataclase é registrada pela distribuição fractal de grãos e fragmentos, dilatância, rotação de corpos rígidos, fluxo cataclástico, microfraturas e microfalhas. Dois eventos cataclásticos foram descritos: (i) durante o Devoniano Inferior $(402 \pm 6 \mathrm{Ma})$ em um regime dúctil-rúptil com temperaturas ate $400^{\circ} \mathrm{C}$ e a geraçáo de protocataclasitos, e (ii) durante o Carbonifero Superior (310.9 $\pm 8 \mathrm{Ma}$ ) em um regime rúptil com temperaturas até $300^{\circ} \mathrm{C}$ e a geração de protocataclasitos e brechas moídas. $E$ Então sugerido que os cataclasitos da ZCC se formaram devido a dois eventos de reativaçáo durante o Paleozóico associados aos efeitos orogênicos Precordillera e Chanica na margem oeste do paleocontinente Gondwana.
\end{abstract}

PALAVRAS-CHAVE: cataclasitos; microestruturas; rochas de falha; idades K-Ar em illitas finas.

${ }^{1}$ Geosciences Institute, Universidade de São Paulo - USP, São Paulo (SP), Brazil. E-mail: claudio.mora@usp.br; ginaldo@usp.br ${ }^{2}$ Geoscience Centre of the University of Göttingen, Göttingen, Germany. E-mail:kwemmer@gwdg.de

*Corresponding author

Manuscrito ID: 30027. Recebido em: 12/09/2013. Aceito em: 14/10/2013. 


\section{INTRODUCTION}

Fault and shear zone conceptual models for a quartzofeldspathic crust (e.g. Sibson 1977; Scholz 2002) summarize $\mathrm{P}-\mathrm{T}$ variations, rock types and deformation mechanisms with depth. At shallow crustal levels (up to $10-14 \mathrm{~km}$ depth) cataclasis takes place in the development of cataclastic rocks, involving brittle fragmentation of rocks or mineral grains with rigid body rotation, cracking, frictional sliding, cataclastic flow and dilatancy (Snoke et al. 1998). Shallow crustal levels are likely to produce these rock types once pressures are not high enough to restrain crack opening nor is temperature to activate intracrystalline plasticity. Brittle fragmentation is related to the seismogenic regime (Sibson 1989), thus being episodic. The base of the seismogenic regime $(10-14 \mathrm{~km}$ depth) is mechanically important because it represents the peak shear resistance and is thought to be the main nucleation environment for great magnitude earthquakes. Once the base of the seismogenic regime is at ca. $14 \mathrm{~km}$ depth and quartz plasticity begins at ca. $10 \mathrm{~km}$ depth with a minimum temperature of $280 \pm 30^{\circ} \mathrm{C}$ (Stipp et al. 2002), there is a pressure-temperature range where brittle and ductile processes overlap, yielding complex tectonites.

Various attempts on fault rock classification (e.g. Waters \& Campbell 1935; Spry 1969; Higgins 1971; Sibson 1977; Schmid \& Handy 1991; Woodcock \& Mort 2008) have been made after the mylonite-type was first described by Lapworth (1885) in the Moine Thrust, Scotland. Most debates regard the importance of genetic and non-genetic connotations used to classify a fault rock. As well-pointed by Woodcock and Mort (2008) the most influential classification of fault rocks by Sibson (1977), regarded as strictly textural-descriptive, is actually genetic, once maintenance of primary cohesion is a main criterion for this classification. Although primary cohesion is an important criterion, it is not easy to assert whether the rock maintained its primary cohesion or was secondarily cemented. According to Higgins (1971), cohesion, if present in fault gouge and fault breccias (i.e. non-cohesive fault rocks), is due to secondary processes. Thus, the distinction between a fine-grained matrix and secondary cement is necessary, even though hardly possible in hand sample or even under the microscope. Primary cohesion is a main criterion for most classifications after Sibson (1977) (e.g. Killick 2003; Passchier \& Trouw 2005; Brodie et al. 2007), however, only Schmid and Handy (1991) have fully discussed this subject. Woodcock and Mort (2008) proposed a grain-size based classification, probably more useful for fieldwork.
In the present study, we aimed to characterize the cataclastic rocks from the Camburu Shear Zone (CSZ) in southeastern Brazil by describing their matrix and microstructures in order to access genetic conditions such as maintenance or not of primary cohesion. Additionally, we report on $\mathrm{K}$-Ar ages and metamorphic conditions associated with the development of these fault-related rocks. The main methods included conventional petrography with microstructural analysis, X-ray diffraction (XRD), scanning electron microscope (SEM) and K-Ar age determinations on illite-rich mineral fine fractions. The latter has proven to be useful in providing insights on the tectonic history of very low-grade metamorphic shear zones (e.g. Lyons \& Snellenberg 1971; Kralik et al. 1987; and more recently Haines \& van der Pluijm 2008; Siebel et al. 2009; Löbens et al. 2010; Zwingmann et al. 2010a, b; Surace et al. 2011; Wolf et al. 2012).

\section{GEOLOGICAL SETTING}

The Camburu Shear Zone (CSZ) is located in the São Sebastião region, at the northern coast of the São Paulo state, southeastern Brazil. The fault is associated with the evolution of the $1400 \mathrm{~km}$ long Ribeira Belt in the Atlantic Brazilian margin. This belt developed through several collage events from the Neoproterozoic to the Eopaleozoic that constructed the western part of the Gondwana paleocontinent (Brito Neves \& Cordani 1991). It is associated with the collision of the São Francisco-Congo and Serra do Mar paleocontinents between $590 \mathrm{Ma}$ and $550 \mathrm{Ma}$ as a result of the Adamastor paleo-ocean closure (Heilbron \& Machado 2003). The central domain of the Ribeira Belt was subdivided by Tassinari and Campos Neto (1988) into three fault-bounded units: the São Roque Domain, the Embu Domain and the Coastal Domain.

The Coastal Domain, which includes the CSZ, extends from the Cubatão Shear Zone to the coastline, also comprising the alkaline complex of the Ilhabela Island (Fig. 1). This domain broadly consists of granitic rocks and high-grade metamorphic terranes. The granitic rocks are represented by either post-tectonic non-foliated massifs and strongly foliated pre- to syntectonic massifs. The first are charnockites and pink porphyritic hornblende-biotite granites, whereas the foliated rocks are muscovite-biotite granites and garnet-bearing leucocratic granites. The metamorphic terranes comprise the Coastal Complex, in which are migmatites with complex structures, porphyroclastic granitic gneisses, biotite/hornblende migmatites, quartzites and amphibolites (Morais 1999). Dias Neto (2001) and Dias Neto et al. (2008, 2009) present a $580 \mathrm{Ma}$ U-Pb (zircon) SHRIMP age for the intrusive basic rocks that originated the amphibolitic 


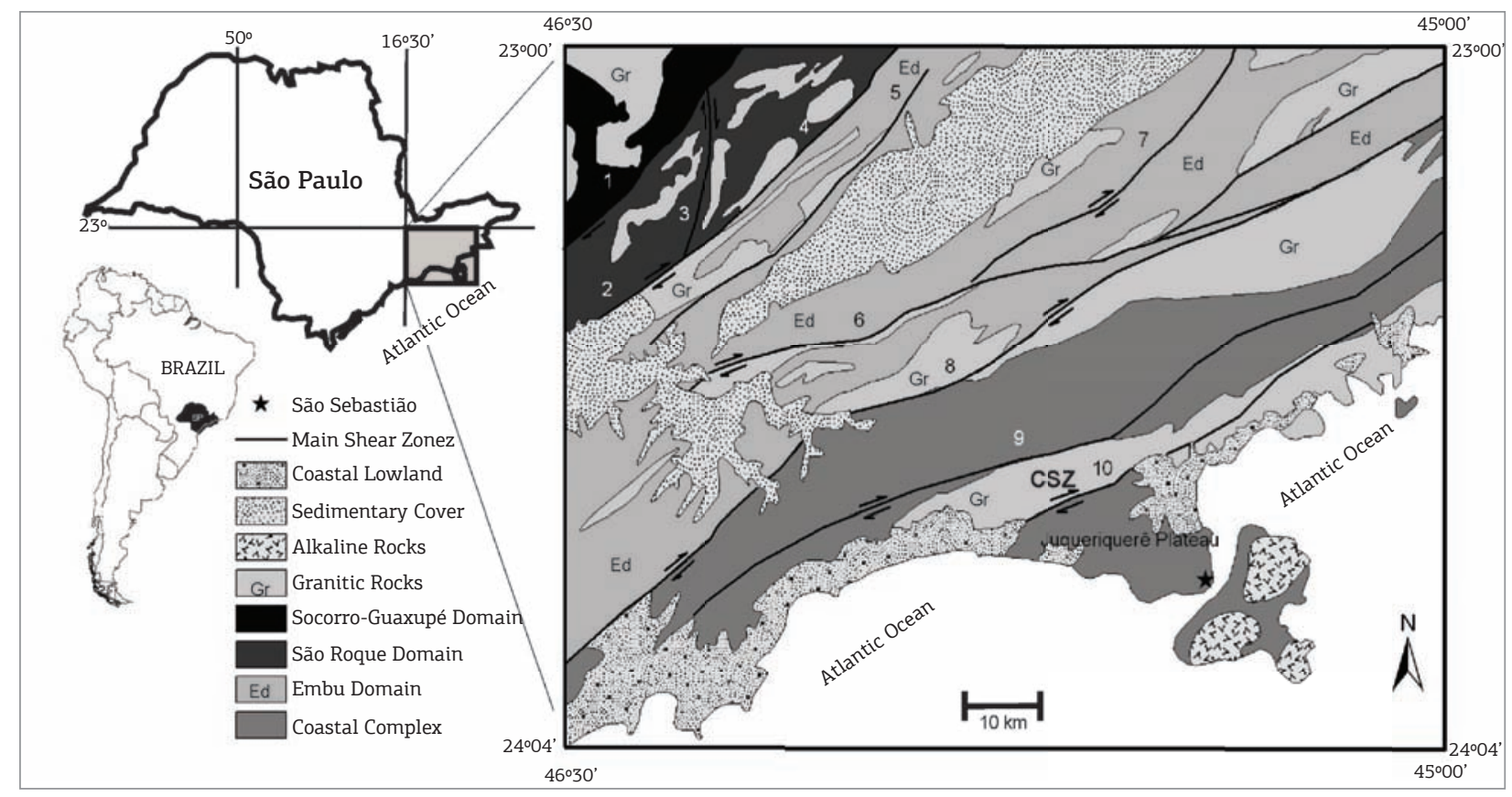

Figure 1. Geological sketch of the northern coast of the São Paulo state, southeastern Brazil. The Camburu Shear Zone (CSZ) defines the northern limit of the Juqueriquerê Plateau. Main shear zones are (1) Jundiuvira, (2) Rio Jaguari, (3) Sertãozinho, (4) Monteiro Lobato, (5) Buquira, (6) Taxaquara, (7) Alto da Fartura, (8) Cubatão, (9) Freires-São Lourenço e (10) Camburu. Adapted from Morais (1999).

rocks of the Coastal Complex, and a $570 \mathrm{Ma}$ age for the metamorphic peak. The temperatures remained very high between 580 and $480 \mathrm{Ma}$, decreasing from 800 to $450^{\circ} \mathrm{C}$ (a rate around $3^{\circ} \mathrm{C} / \mathrm{Ma}$ ). Tassinari et al. (2006) stated that after $480 \mathrm{Ma}$, the cooling rate was much faster than $3^{\circ} \mathrm{C} / \mathrm{Ma}$. During the Mesozoic the Coastal Complex underwent significant volcanism. At first, $140 \mathrm{Ma}$ to $110 \mathrm{Ma}$ basic rocks (Minioli 1971) arose as a result of the Atlantic Ocean opening, and later, 95 to $45 \mathrm{Ma}$, mantle plume related alkaline rocks were formed (Zalán \& Oliveira 2005).

Only a few studies have been published concerning cataclastic rocks within the Ribeira Belt. Ferrari Riccomini (2003) described silicified tectonic breccias in the Rio de Janeiro state and related them to a late stage of the Early-Cenozoic alkaline magmatism, ca. $40 \mathrm{Ma}$ ago. Motoki et al. (2011) also described tectonic breccias in the Rio de Janeiro State that were intruded by 135 Ma mafic dykes, postulating that these cataclastic rocks are evidence for a Pan-African brittle tectonism.

\section{The Camburu Shear Zone (CSZ)}

The CSZ is a NE-SW trending dextral transcurrent fault (Fig. 1), being a meter to hundreds of meters wide belt of quartzo-feldspathic mylonitic rocks, also comprising metric to centimetric thick intercalations of cemented cataclastic rocks (Campanha et al. 1994). It separates two lithologies that belong to the Coastal Domain: the Pico do Papagaio Granite to the NW of the fault, and the Augen Gneisse Juqueí to its SE (Fig. 2). The first is a hornblende monzogranite with a well-developed foliation, which turns into a mylonitic structure towards the fault. Tassinari (1998) presented a Rb-Sr whole-rock age of $543 \pm 16 \mathrm{Ma}$ for this granite. The second lithology is a biotite granite with a blastomylonitic structure and a $633 \pm 59 \mathrm{Ma} \mathrm{Rb}-\mathrm{Sr}$ whole rock age (Dias Neto 2001). The Precambrian to early Paleozoic ductile regime of the CSZ is characterized by a penetrative metamorphic foliation, mineral stretching lineations and asymmetric porphyroclasts. By associating the fan-like distribution of the foliation and the local divergent thrusts (Fig. 2), Campanha \& Ens (1996) suggested a compressive regime and describe a ductile positive flower structure.

\section{METHODS}

\section{X-Ray diffraction}

The XRD was conducted through the powder method particularly in the fine-grained matrix of the selected samples (Figs. 3C and D). The X-Ray diffractor used is a PANanalytical, X'Pert PRO with an X'Celerator 
detector. The analytical conditions were: $\mathrm{Cu}$-source of $\mathrm{X}$-rays under $45 \mathrm{kV}$ and $40 \mathrm{~mA}$, angular interval of $4^{\circ}$ to $70^{\circ} 2 \mathrm{Q}$ with $0.02^{\circ}$ step width and integration time of $20 \mathrm{~s}$ per step. Crystalline phases were obtained by comparing the analyzed diffraction pattern to the PFD2 database (International Centre for Diffraction Data 2003) and to the PAN-ICSD, PANalytical Inorganic Crystal Structure
Database 2007. Semi-quantitative determinations were carried out by the Ratio Intensity Reference (RIR) method (Johnson \& Zhou 2000) with crystalline phases from the ICSD database (Inorganic Crystal Structure Database National Institute of Standards and Technology, NIST, and Fachinformationszentrum Karlsruhe, FIZ - year 2007).

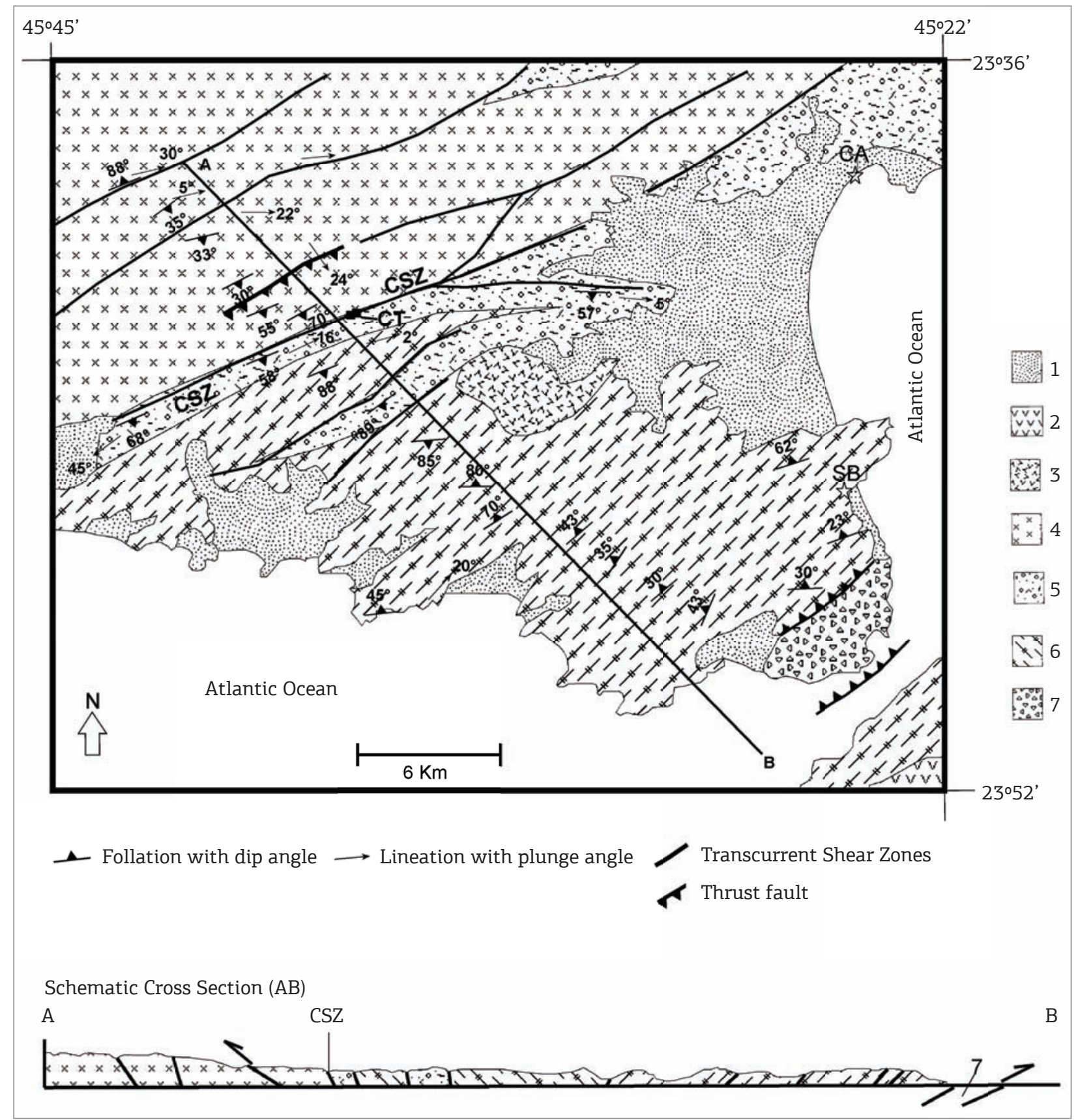

Figure 2. Geological map of the Juqueriquerê Plateau and schematic cross-section (AB): (CSZ) Dextral Camburu Shear Zone; (CT) Sampled cataclastic rocks; (CA) Caraguatatuba city; (SB) São Sebastião city; (1) Quaternary sedimentary cover; (2) Ilha Bella Alkaline rocks; (3) Bairro do Marisco Complex: Meta-gabro, diorite, enderbite and amphibolite; (4) Pico do Papagaio Granite; (5) Augen Gneiss Juqueí; (6) Gneisses and Migmatites of the Coastal Complex; (7) Garnet-bearing gneissic leucogranite. 


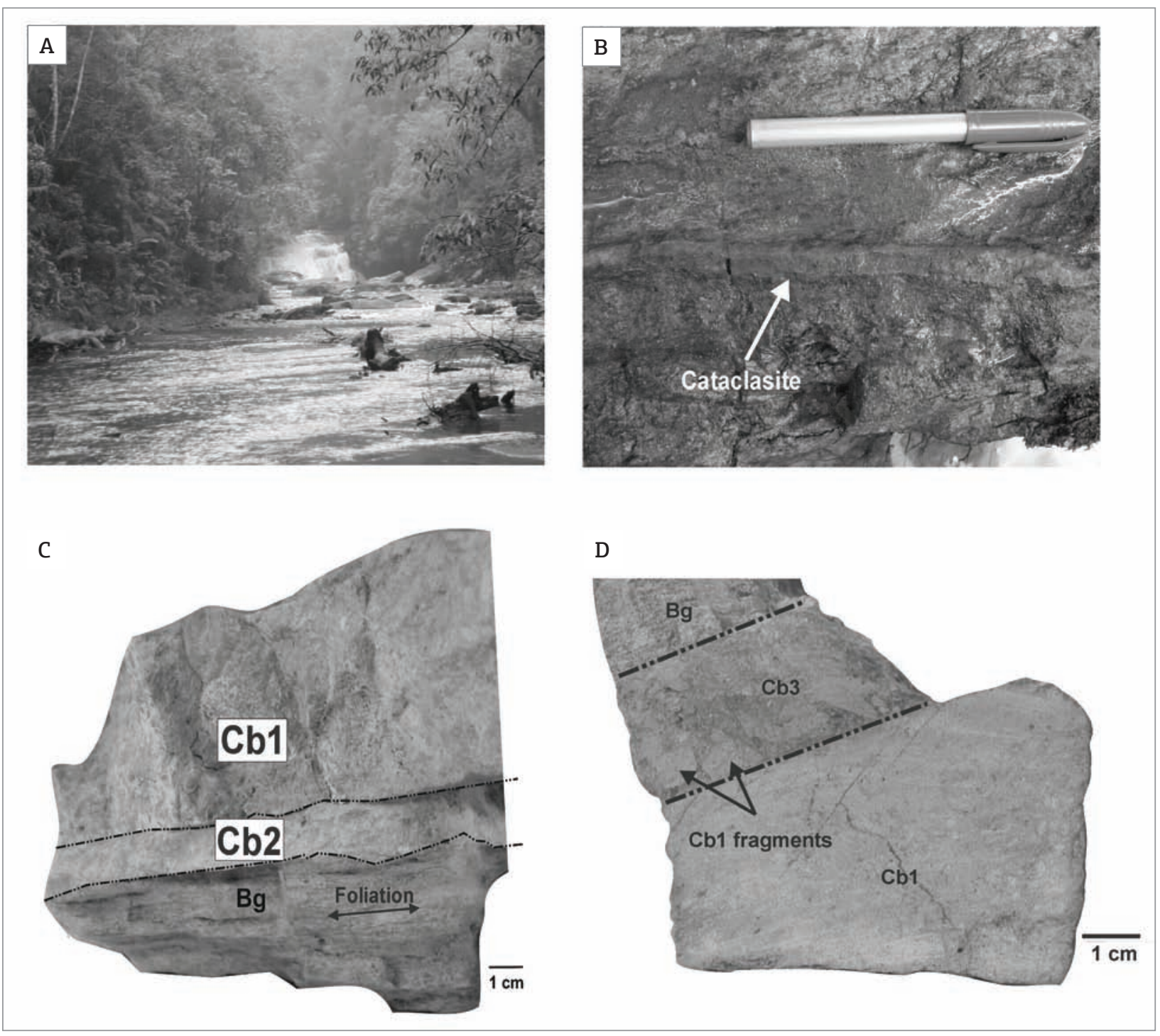

Figure 3. (A) Outcrops within the Camburu River; (B) Mylonitic biotite gneiss with fine band of cataclasite parallel to mylonitic foliation. Pen shows foliation trace; (C) Hand sample of $\mathrm{Cb} 1$ and $\mathrm{Cb} 2$ parallel to the foliation of the protolith (Bg); (D) Cb1 and Cb1 fragments-bearing Cb3 parallel to protolith foliation (Bg).

\section{Scanning electron microscope}

Electron backscattered images were obtained from thin sections as well as mineral phase identification through electron dispersive spectroscopy (EDS). Secondary electron images were obtained in little rock fragments. Both thin sections and rock fragments of the selected samples were covered with a thin carbon film in the carbon evaporator SCD 50 Sputter Coated from Basaltec. Imaging was conduced on the LEO Stereoscan 440 microscope. EDS analysis uses Oxford-INCA spectrometer with silicon detector. The analytical conditions were established as $30000 \mathrm{nA}, 20 \mathrm{kV}$ and distance work of $24-25 \mathrm{~mm}$.

\section{Analytical procedure for $\mathrm{K}-\mathrm{Ar}$ dating}

The Ar isotopic composition was measured in a VG $12000 \mathrm{C}$ noble gas mass spectrometer operating in static mode after extraction and purification in a coupled pyrex glass line. The amount of radiogenic ${ }^{40} \mathrm{Ar}$ was determined by isotope dilution method using a highly enriched ${ }^{38} \mathrm{Ar}$ spike from Schumacher (1975). The spike is calibrated against the biotite standard HD-B1 (Fuhrmann et al. 1987). The age calculations are based on the constants recommended by the IUGS quoted in Steiger and Jäger (1977). K was determined in duplicate using a Perkin-Elmer AAS 5100 PC. For K analysis the standard DR-N, Mica-Fe and GSN were used (Govindaraju 1995). The samples were dissolved 
in a mixture of $\mathrm{HF}$ and $\mathrm{HNO}_{3}$ according to the technique of Heinrichs and Herrmann (1990). $\mathrm{CsCl}$ is added as an ionisation buffer. The ${ }^{40} \mathrm{Ar} /{ }^{36} \mathrm{Ar}$ ratio of air shots was monitored continuously and used for correction of all ratios needed for the age calculation. For this set of analysis, the ratio was 301.0. The analytical error for the $\mathrm{K}-\mathrm{Ar}$ age calculations is given on a $95 \%$ confidence level $(2 \sigma)$. Details of Ar and K analyses for the laboratory in Göttingen are given in Wemmer (1991).

\section{Sample preparation and measurement of the Kübler Index}

The selected samples (Figs. 3C and D) were processed for the separation of the fine mineral fractions $(<2$ and $<0.2 \mu \mathrm{m})$ needed for K-Ar age and Kübler Index (KI) determinations. The cataclastic layers $(\mathrm{Cb} 1, \mathrm{Cb} 2$ and $\mathrm{Cb} 3)$ were released carefully using a chisel, gently crushed with a pestle and split into size fractions $>63$ and $<63 \mu \mathrm{m}$. The fractions $<63 \mu \mathrm{m}$ were used to extract the clay fractions $<2 \mu \mathrm{m}$ by settling in Atterberg cylinders. A second $<2 \mu \mathrm{m}$ fraction was gained the same way and used to separate the fractions $<0.2 \mu \mathrm{m}$ using an ultra-centrifuge. All these fine fractions were examined through XRD for mineralogical composition and illite crystallinity, which was measured as the peak width at half height of the 10- $\AA$ peak and is expressed by the KI (Kübler 1967, 1968). Digital measurement of KI was carried out by step scan (301 points, $7-10^{\circ} 2 \theta$, scan step $0.010^{\circ} 2 \theta$, integration time $4 \mathrm{~s}$, receiving slit $0.1 \mathrm{~mm}$, automatic divergence slit) on a Philipps PW 1800 diffractometer. All samples were investigated in duplicates (A and B). The measurements were carried out in the air-dry and the glycolated status in order to detect expandable layers of smectite.

$\mathrm{KI}$ values are given in $\left(\Delta^{\circ} 2 \theta\right)$. The limits for diagenesis/anchizone and anchizone/epizone are $0.600^{\circ}$ to $0.400^{\circ}$ and $0.240^{\circ} \Delta^{\circ} 2 \theta$, respectively. These limits were checked in the interlaboratory standardization program of Warr and Rice (1994). The given KI values are nearly identical to the crystallinity index standard (CIS). According to Warr (1996), the following correlation to mineral facies is appropriate: diagenetic zone to the zeolite facies, anchizone to the prehnite-pumpellyite facies plus the pumpelyite-actinolite facies and epizone to the beginning of grenschist facies. Although mineral facies overlap considerably (e.g. Fig. 10 of Frey et al. 1991), correlating the anchizone with the prehnite-pumpellyite facies indicates a P-T field from about 175 to $280^{\circ} \mathrm{C}$ and 0.5 to $4.5 \mathrm{kbar}$, while inclusions of the pumpellyite-actinolite facies extends the temperature field up to a maximum of about $320^{\circ} \mathrm{C}$ at pressures below 4 kbar.

\section{PETROLOGICAL AND MICROSTRUCTURAL FEATURES}

\section{Mesoscopic features}

The CSZ rocks are very difficult to sample because their main outcrops are within the Camburu River (Fig. 3A). Additionally, the cataclastic bands do not occur as a continuous body along the fault zone (e.g. Sibson 1977, 1986, 1989, 2000), whilst mylonitic rocks do. Thus, sampling of the cataclastic rocks is rather limited. Nevertheless, these rocks record interesting microstructures from which temperature and pressure constrains can be inferred. Accurately separation of fine-fraction illites permitted age determinations (see following sections), which supported macro- and microscopic structures.

The Camburu river flows towards SE until it reaches the CSZ where it aligns to the fault and thereafter flows towards NE. The main rock type is a mylonitic biotite gneiss with a penetrative upright (up to $80^{\circ}$ ) foliation in which the centimeter-thick cataclastic bands can be recognized (Fig. 3B). A particular contrasting feature between the mylonitic and cataclastic rocks, in this case, is random vs. oriented fabric.

In hand specimen samples, three different cataclastic bands (henceforth referred to as $\mathrm{Cb} 1, \mathrm{Cb} 2$ and $\mathrm{Cb} 3$ ) can be described (Figs. 3C and D). Cb1 is 6-cm thick and matrix-supported. The matrix is grey and its components are too fine to be identified. It supports $1-2 \mathrm{~cm}$ pink polycrystalline fragments that show angular-shaped terminations. $\mathrm{Cb} 2$ is a white porcelain-like band with maximum of $2 \mathrm{~cm}$ in thickness. Under magnifying glasses it is possible to see a non-foliated matrix-supported fabric. This band often occurs at the interface between the $\mathrm{Cb} 1$ and the mylonitic biotite gneiss, and even thinner bands may occur between $\mathrm{Cb} 3$ and the mylonitic biotite gneiss. Whilst $\mathrm{Cb} 1$ and $\mathrm{Cb} 2$ show higher contents of matrix and lower contents of clasts (thus, showing a matrix-supported structure), $\mathrm{Cb} 3$ shows higher contents of polycrystalline fragments and lower contents of matrix. The color of $\mathrm{Cb} 3$ ranges from brown to ocher and its thickness do not exceed $5 \mathrm{~cm}$. The clasts (i.e. single grains or polycrystalline fragments) contained in $\mathrm{Cb} 3$ are highly angular-shaped and some resemble $\mathrm{Cb} 1$, suggesting that $\mathrm{Cb} 3$ formed after $\mathrm{Cb} 1$.

\section{Petrography and microstructures}

The protolith of the cataclastic rocks is a mylonitic biotite gneiss of monzogranitic composition. The matrix grain size is fine to medium and the porphyroclasts range from 0.5 to $1.1 \mathrm{~cm}$ in size. Quartz and feldspar are distributed in an inequigranular granoblastic texture with interlobate to 
polygonal grain boundaries. Where polygonal, quartz lacks undulose extinction, although there are some preserved bulging-recrystallization domains with undulose extinction. Feldspars are rarely twinned and highly altered to sericite. The lepidoblastic texture is defined by biotite concentrated within the matrix grain boundaries and defining the foliation parallel to the long axis of the deformed quartz and feldspar.

$\mathrm{Cb} 1$ is matrix-supported with a typical cataclastic texture in which grains (Fig. 4E) and polycrystalline fragments are randomly distributed in a fine-grained matrix showing different grain size distributions. Quartz, K-feldspar and plagioclase, vary from 0.1 to $1.0 \mathrm{~mm}$ in size, whereas polycrystalline fragments vary from 0.1 to $3.8 \mathrm{~mm}$. Both variations of clasts are angular-shaped to sub-rounded, neither of them being internally microfractured. Unlike the grains, polycrystalline fragments preserve some plastic deformation related features, such as undulose extinction and lobate grain boundaries, resembling dynamically recrystallised domains of the protolith (Fig. 4G). The matrix represents up to $35 \%$ of the rock and comprises fine-grained $(<0.1 \mathrm{~mm})$ phyllosilicates in a highly decussate texture. Feldspars were also highly altered to fine white micas.

On the microstructures, $\mathrm{Cb} 1$ contains a microfault filled by opaque materials in which are randomly distributed finegrained fragments (Figs. 4A, B and 5F). Obliquely to the microfault, a set of microcracks extends towards the protolith. These microcracks occur across the matrix as well as across the grains and polycrystalline fragments (Figs. 4A and C), thus being classified as critical transgranular microcracks (Blenkinsop 2000; Schmid \& Handy 1991). Close to coarsegrained polycrystalline fragments a microfault-induced cataclastic flow - devoid or with incipient plastic deformation is preserved as a cataclastic foliation (Figs. $4 \mathrm{~B}$ and $\mathrm{D}$ ), being characterized by the orientation of grains and fragments embedded in an anastomosing-like matrix of fine-grained micas and microcracks filled by opaque minerals.

$\mathrm{Cb} 2$ is matrix-supported and also exhibits a cataclastic texture (Fig. 4E). Grain size is the most important feature to characterizing this band as it is the finer among the three cataclastic bands, ranging from 0.025 to $0.25 \mathrm{~mm}$ in size. Grains are more abundant than polycrystalline fragments, both being angular-shaped. The matrix - in this case defined as $<0.025 \mathrm{~mm}$ - represents $45 \%$ of the rock being light-brown in color and isotropic under crossed polarized light. In the thicker portions, $\mathrm{Cb} 2$ shows a very finegrained sharp contact with the protolith (Fig. 4F), ranging to coarser fractions in the center of the cataclastic band and decreasing towards the opposite contact.

$\mathrm{Cb} 3$ is clast-supported with a minor proportion of opaque mineral in the matrix (Fig. 4G). Angular-shaped grains of quartz and feldspar with a grain size from 0.2 to $0.6 \mathrm{~mm}$ are dispersed in this matrix. Highly angular-shaped polycrystalline fragments are of dominant content, varying from 0.2 to $0.8 \mathrm{~cm}$ in size. They are either quartzo-feldspathic with an internal inequigranular lobate-to-polygonal granoblastic texture, resembling the protolith, or fragments of $\mathrm{Cb} 1$. The latter clearly contain a sub-rounded fragment from the protolith and are the coarser fractions $(1-1.3 \mathrm{~cm})$. Subcritical intragranular microcracks are abundant.

SEM observations show that the cataclastic texture reaches the nanoscale, supporting the fractal character of these rocks, typical of cataclastic rocks (Blenkinsop 2000). $\mathrm{Cb} 2$ shows well-developed micas with 1.8 to $2.7 \mu \mathrm{m}$ in size, and still finer well-developed micas were observed at the interface between $\mathrm{Cb} 1$ and $\mathrm{Cb} 2$ with 0.5 to $1.5 \mu \mathrm{m}$ in size. A clear texture of coronitic white mica around feldspar grains might suggest feldspar-to-mica reactions. EDS microanalysis showed that the opaque material infilling microfaults and microcracks as well as composing the $\mathrm{Cb} 3$ matrix is iron oxide (Figs. 5C - F).

Two families of slickenlines (Figs. 5A and B) at the interface between $\mathrm{Cb} 1$ and $\mathrm{Cb} 2$ are observed in secondary electron images, one being directional $\left(233^{\circ} / 12^{\circ}\right)$ and fiber-rich and other being dip-slip $\left(200^{\circ} / 68^{\circ}\right)$ devoid of newly-grown fibers. Crosscutting relations show that the latter are younger than the directional slickenlines.

\section{MINERALOGICAL VARIATION AND XRD PATTERNS OF THE FINE- GRAINED MATRIX}

Whole-rock XRD patterns and semi-quantitative percentage of crystalline phases are shown in Figs. 6A and B.

Albite, K-feldspar and quartz are the main components comprising the matrix of $\mathrm{Cb} 1, \mathrm{Cb} 2$ and $\mathrm{Cb} 3$, roughly representing the same bulk composition of the protolith. Biotite is only present in the protolith, suggesting that this mineral was maintained stable in the protolith during cataclasis. To the other hand, white micas are only present in $\mathrm{Cb} 1$, $\mathrm{Cb} 2$ and $\mathrm{Cb} 3$, possibly suggesting that they were formed as a result of cataclasis. Kaolinite was detected only in $\mathrm{Cb} 2$ and $\mathrm{Cb} 3$, which showed a higher degree of weathering in hand sample.

The mineral composition of the investigated fine fractions $(<2$ and $<0.2 \mu \mathrm{m})$ is totally different, they consist mainly of illite and kaolinite (Fig. 7) with only minor occurrence of quartz and feldspar. As kaolinite does not contain $\mathrm{K}$ any impact on the $\mathrm{K}$-Ar age can be excluded. Concerning the ratio of both clay minerals, $\mathrm{Cb} 1$ is dominated by illite (4.15 to 5.59 wt.\% of $\mathrm{K}_{2} \mathrm{O}$; Tab. 1), whereas $\mathrm{Cb} 2$ and $\mathrm{Cb} 3$ contain more kaolinite than illite (1.01 to 2.51 wt.\% of $\mathrm{K}_{2} \mathrm{O}$; Tab. 1). 


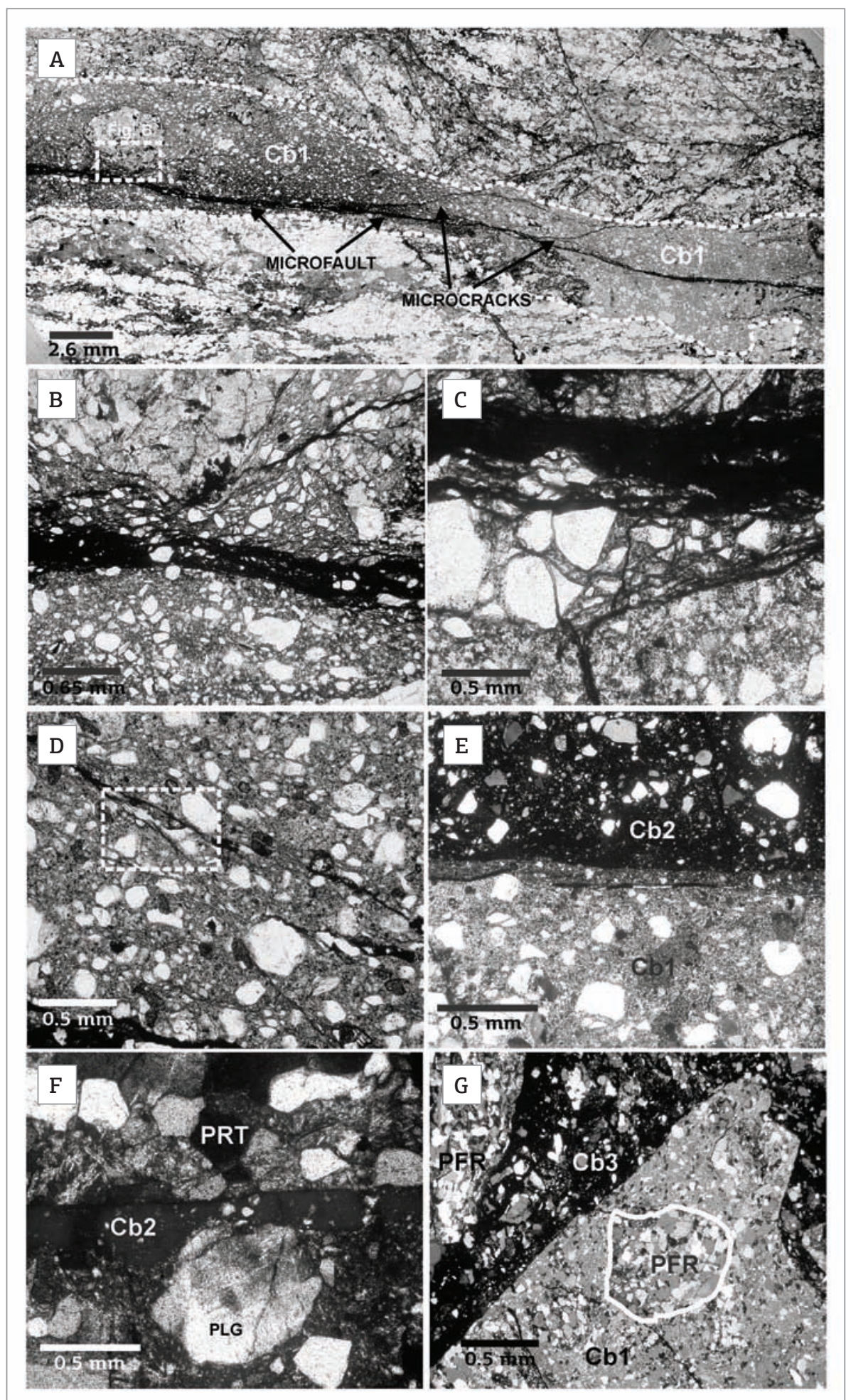

Figure 4. Thin section photographs. (A) Microfault filled with iron oxide and oblique microcracks; (B) Detail of microfault in A showing that the microstructure contains randomly distributed fragments. Note the cataclastic foliation at the top of the microfault associated to a coarse polycrystalline fragment; (C) Detail of critical transgranular microcracking, cutting either the matrix and an optic-continuous crystal; (D) Cb1 showing plasticdeformed crystals of quartz; (E) Isotropic matrix of Cb2 and sharp contact with Cb1; (F) Protolith (PRT) and sharp contact with $\mathrm{Cb} 2$; (G) Iron oxide rich matrix of $\mathrm{Cb} 3$ with polycrystalline fragments of the protolith (PFR) and of $\mathrm{Cb} 1$, with also contains a polycrystalline fragment of the protolith. 

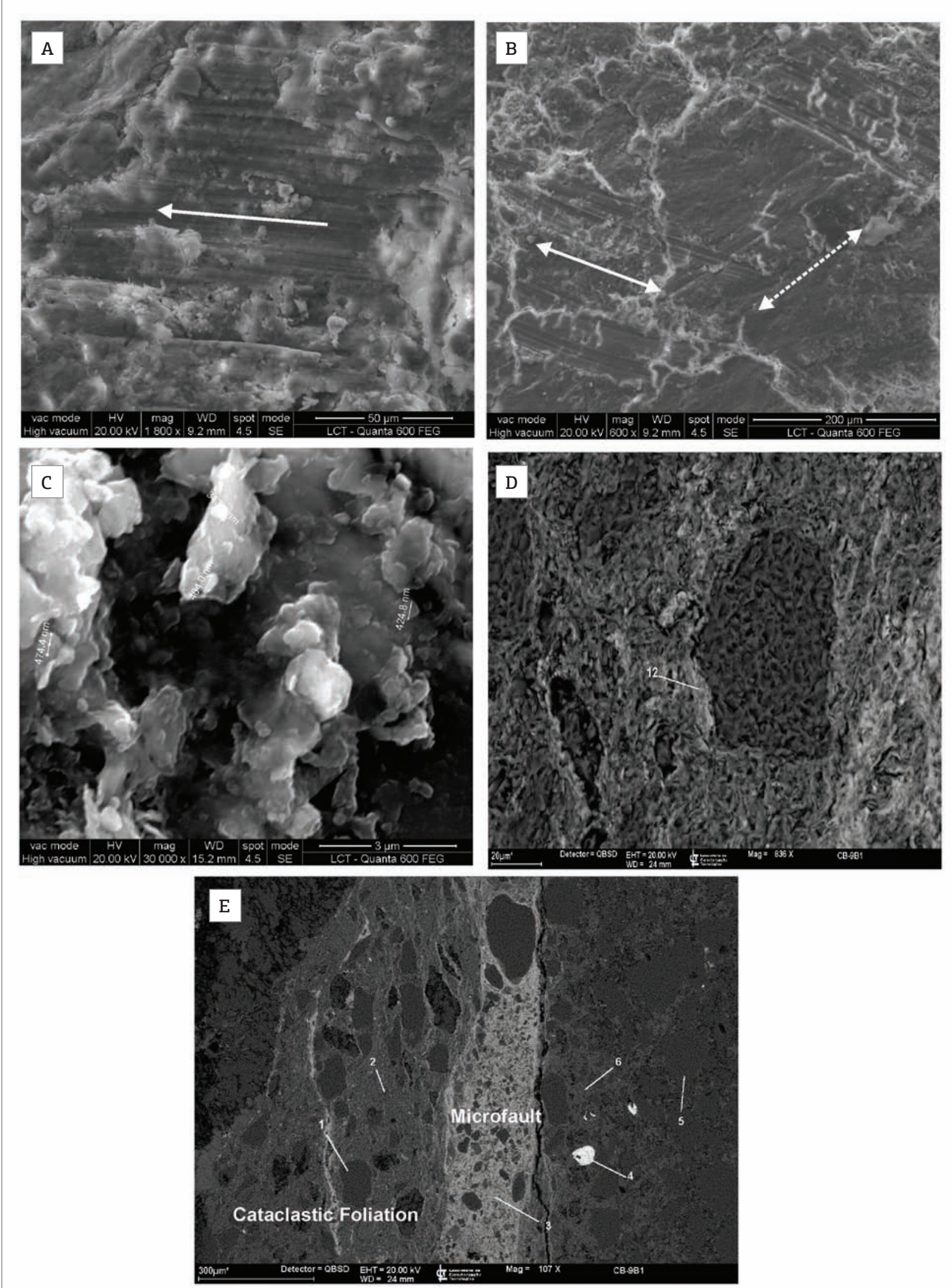

Figure 5. (A) Secondary electron image of fiber-rich directional slickenline; (B) crosscut relation of the younger dip-slip slickenline (NE-SW-trending in the image); (C) very fine-grained euhedral newly-grown mica; (D) coronitic texture of white mica replacing a feldspar crystal; (E) microfault at the centre with white colors and cataclastic foliation at left. 
The protolith contains less quartz, more K-feldspar and no white mica with respect to the three cataclastic bands. Therefore, it is suggested that fine authigenic and newly-grown white micas are a result of K-feldspar consumption. This is supported by the coronitic white mica around feldspar crystals (Fig. 5D) and the very fine-grained euhedral newly-formed mica (Fig. 5C).

Table 1. Compilation of the $\mathrm{K}$-Ar ages and the Illite Crystallinity Index of mineral fine fractions

\begin{tabular}{|c|c|c|c|c|c|c|c|c|}
\hline \multirow{2}{*}{ Samples } & \multirow{2}{*}{$\begin{array}{c}\text { Grain } \\
\text { fractions } \\
(\mu \mathrm{m})\end{array}$} & \multicolumn{5}{|c|}{$\mathrm{K}$-Ar data } & \multicolumn{2}{|c|}{ Illite Crystallinity } \\
\hline & & $\mathrm{K}_{2} \mathrm{O}(\mathrm{wt} \%)$ & $\begin{array}{c}{ }^{40} \mathrm{Ar} \mathbf{r}^{*}(\mathrm{nl} / \mathrm{g}) \\
\text { STP }\end{array}$ & ${ }^{40} \mathrm{Ar}^{*}(\%)$ & Age (Ma) & $\begin{array}{c} \pm 2 \sigma \text {-error } \\
(\mathrm{Ma})\end{array}$ & $\begin{array}{l}\text { Air dry } \\
D^{\circ} 2 q\end{array}$ & $\begin{array}{l}\text { Glycolated } \\
D^{\circ} 2 q\end{array}$ \\
\hline \multirow[t]{2}{*}{$\mathrm{Cb} 1$} & $<2$ & 5.59 & 82.94 & 98.51 & 409.8 & 6.6 & 0.155 & 0.157 \\
\hline & $<0.2$ & 4.15 & 59.15 & 97.86 & 395.3 & 5.8 & 0.149 & 0.142 \\
\hline \multirow[t]{2}{*}{$\mathrm{Cb} 2$} & $<2$ & 2.51 & 30.23 & 96.52 & 339.4 & 6.4 & 0.211 & 0.195 \\
\hline & $<0.2$ & 2.33 & 24.45 & 93.49 & 310.4 & 6.7 & 0.167 & 0.165 \\
\hline \multirow[t]{2}{*}{$\mathrm{Cb} 3$} & $<2$ & 1.42 & 17.15 & 90.63 & 340.3 & 13.7 & 0.210 & 0.215 \\
\hline & $<0.2$ & 1.01 & 11.07 & 87.86 & 311.4 & 9.6 & 0.168 & 0.175 \\
\hline
\end{tabular}

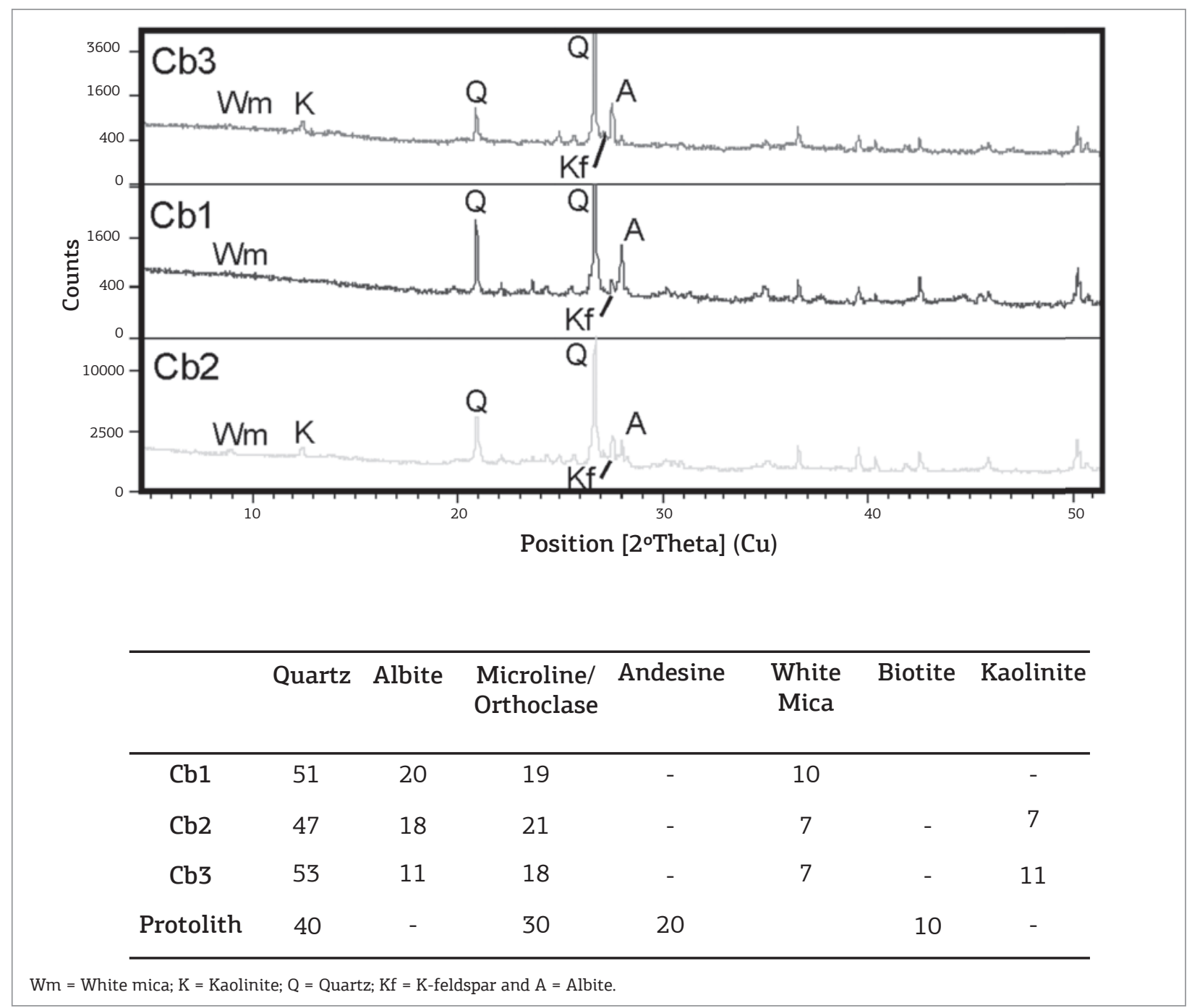

Figure 6. (A) Comparison of the diffractograms for the three cataclastic bands. (B) semi-quantitative percentage of crystalline phases for the three cataclastic bands and the protolith. 
The relatively higher contents of quartz in $\mathrm{Cb} 1, \mathrm{Cb} 2$ and $\mathrm{Cb} 3$ - in respect to the protolith - show that these rocks were enriched in silica during cataclasis. Feldsparto-mica reactions (e.g. Evans 1990; Wibberley 1999) release large amounts of silica as a result of the formation of white micas over the consumption of feldspars. As it is shown by the mineralogical variations and textural relationships, it is very likely that feldspar-to-mica reactions took place during cataclasis.

\section{K-AR ILLITE FINE-FRACTION AGES AND KÜBLER INDEX}

Figs. 8 and 9, respectively, show K-Ar ages and the KI of the three cataclastic bands and the analytical results are shown in Tab. 1. There is a clear difference between $\mathrm{K}$-Ar ages and $\mathrm{KI}$ values when comparing $\mathrm{Cb} 1$ to the other two bands, although all $\mathrm{KI}$ values plot within the epi-zonal field (i.e. $\mathrm{T}>300^{\circ} \mathrm{C}$ in greenschist facies). $\mathrm{Cb} 1$ varies in age from $409.8 \pm 6.6 \mathrm{Ma}(<2 \mu \mathrm{m})$ to $395.3 \pm 5.8 \mathrm{Ma}(<0.2 \mu \mathrm{m})$ and exhibit minor difference in KI for either air-dried and glycolated experiments, all around $0.150 \Delta^{\circ} 2 \theta . \mathrm{Cb} 3$ and $\mathrm{Cb} 2$ are similar in showing older ages ( $340.3 \pm 13.7$ to $339.4 \pm 6.4 \mathrm{Ma}$, respectively) for the $<2 \mu \mathrm{m}$-fraction and higher KI values (around $\left.0.200 \Delta^{\circ} 2 \theta\right)$ for either air-dried and glycolated experiments. Younger ages $(311.4 \pm 9.6$ to $310.4 \pm 6.7 \mathrm{Ma})$ are related to the $<0.2 \mu \mathrm{m}$-fraction which exhibit $\mathrm{KI}$ around $0.16 \Delta^{\circ} 2 \theta$ for both types of experiments.

As $\mathrm{Cb} 1$ yields similar K-Ar ages and similar IC in both fractions, it could reflect a homogeneous illite fraction derived from a short and single deformation event. Once it is the oldest (ca. $402 \pm 6 \mathrm{Ma}$ mean age) and KI values point to high temperatures in the epizone (low IC), it could represent the onset of cataclastic deformation. Under such high temperatures, small crystals of illite are still likely to grow after the deformational event, thus, yielding slightly younger ages for $<0.2 \mu \mathrm{m}$ illite fractions. These ages should be comparable to ${ }^{40} \mathrm{Ar} /{ }^{39} \mathrm{Ar}$ cooling ages of biotites of the protolith.

The ca. $30 \mathrm{Ma}$ difference between the two fractions of $\mathrm{Cb} 2$ and $\mathrm{Cb} 3$ could reflect a ca. $340 \mathrm{Ma}(339.8 \pm 10 \mathrm{Ma}$; mean age for $<2 \mu \mathrm{m}$ fractions) cataclastic event followed by a final third event around $310 \mathrm{Ma}(310.9 \pm 8 \mathrm{Ma}$; mean age for $<0.2 \mu \mathrm{m}$ fractions). A more likely possibility is that a second cataclastic event took place around $310 \mathrm{Ma}$. The older ages of $340 \mathrm{Ma}(<2 \mu \mathrm{m}$ fractions $)$ could be interpreted as a mixture of $310 \mathrm{Ma}$ newly-grown illites with inherited illites from the protolith or even from the first cataclastic event.

\section{DISCUSSION}

\section{Deformation mechanisms and feldspar-to-mica reactions}

One of the main microstructures common to the three cataclastic bands is the grain size distribution. From hand sample to the millimetric scale, angular-shaped grains, fragments of grains or polycrystalline fragments are supported by a finer matrix of roughly the same composition, which characterizes a cataclastic texture. This texture highly resembles the fractal behavior typical for cataclastic rocks sensu strictu

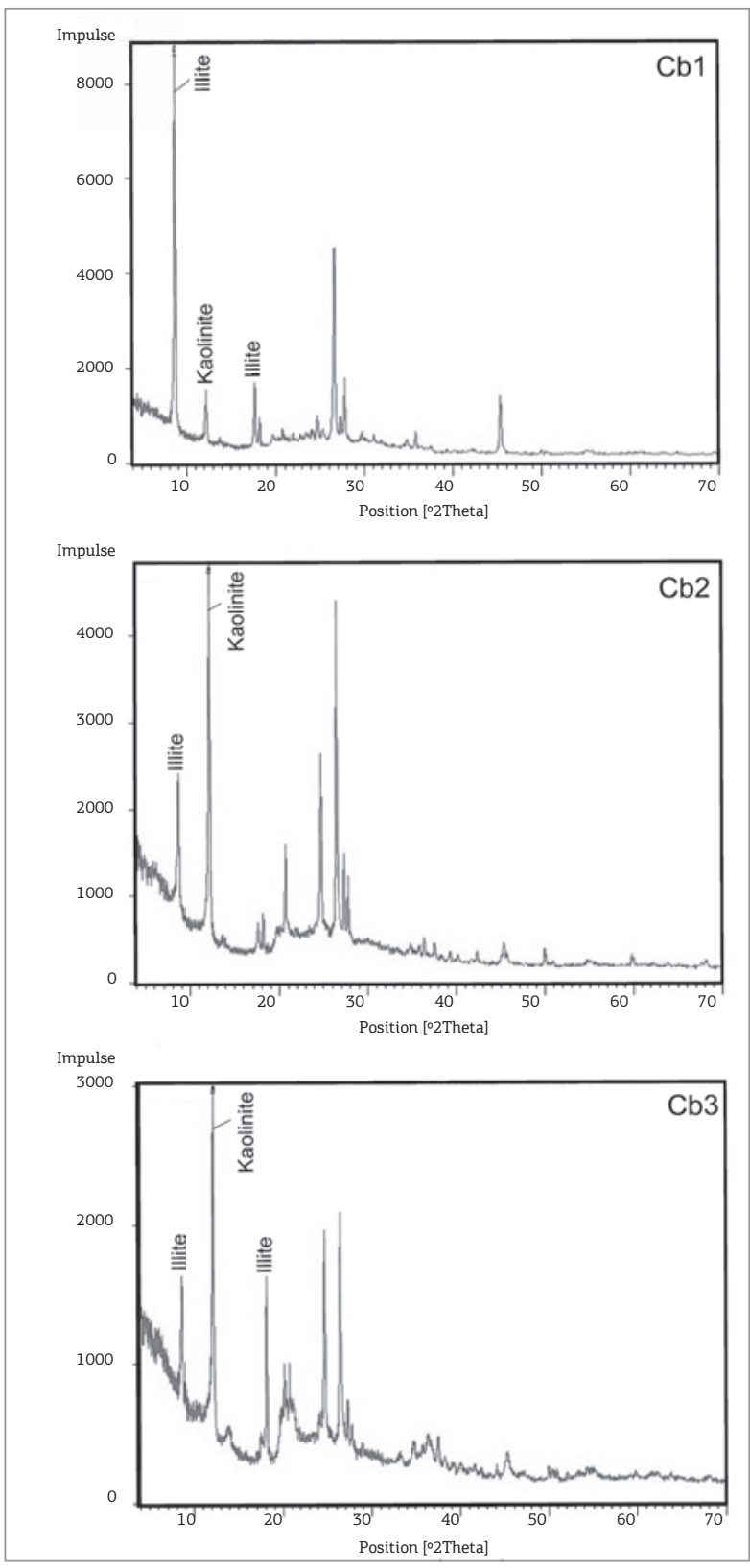

Figure 7. Diffractograms for the fine fractions $(<2 \mu \mathrm{m})$ of the three cataclastic bands. 


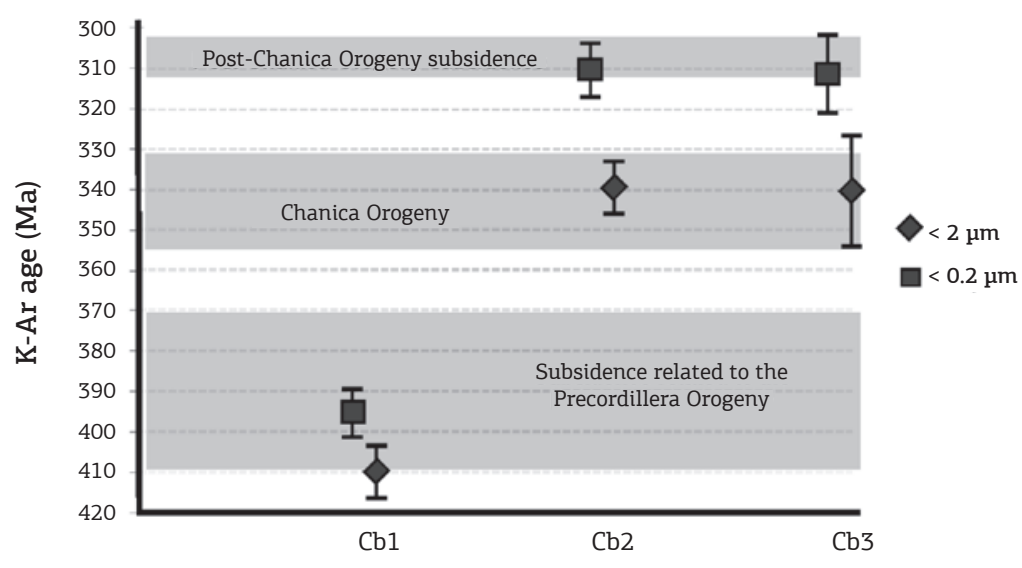

Figure 8. Plot of K-Ar ages and their possible relation to main tectonic events (see text for discussion).

(Blenkinsop 2000) and results from brittle fragmentation. Under higher magnifications, however, grains tend to be sub-rounded to euhedral. The first must have undergone more brittle wear than the coarser fractions, whereas the well-formed crystals (e.g. Fig. 4C) must be newly formed. The importance of the latter is that they might record thermo-tectono events where very fine-grained micas formed, possibly soon after cataclastic deformation ceased.

The general misfit of grains or fragments suggests rigid-body rotation as an acting deformation mechanism, which results from rotation-assisted brittle fragmentation without intracrystalline deformation. However, Fig. 4D shows one or two sigma-like quartz grains indicating concurrent plastic and brittle deformation, the latter being dominant. Sibson (1986) suggested that the general misfit between fragments is a typical feature of implosion breccias, where dilatancy is one of the main features.

During rigid-body rotation and brittle fragmentation, coarser fragments tend to dominate the local rheology of the rock, being then wrapped by a finer fraction matrix which might have its fragments orientated. This orientation is the result of the cataclastic flow and develops a non-penetrative cataclastic foliation (e.g. Figs. $4 \mathrm{~B}$ and 5F). According to Schmid and Handy (1991), cataclastic flow acts to accommodate deformation at particular domains in order to maintain primary cohesion before thorough fragmentation.

Microcracks can be classified as intragranular, when within single crystals, or transgranular, when cutting across two or more grains. The first type is common in poorly cemented and highly porous rocks, whereas the second develops in well-cemented and low-porous rocks (Blenkinsop 2000). Microcracks can additionally be subclassified as critical or subcritical. The first crosscut either grains or the matrix and are typical of highly unstable seismic regimes; the latter type of microcrack is limited to singles crystals and commonly occurs in stable seismic regimes (Schmid \& Handy 1991).
In summary, it is possible to infer that $\mathrm{Cb} 1$ maintained its primary cohesion (because of the cataclastic foliation and transgranular microcracking), underwent dilatancy (rigid-body rotation), and is associated to an unstable seismic regime (critical microcracking). $\mathrm{Cb} 2$ did not preserve important microstructures, however its ultrafine grain sizes and porcelain-like character suggest that dilatancy did not take an important role. $\mathrm{Cb} 2$ might be related to the crush breccias of Sibson (1986). $\mathrm{Cb} 3$ is less cohesive than $\mathrm{Cb} 1$ and $\mathrm{Cb} 2$, as suggested by the intragranular microcracking, the lack of cataclastic foliation and the degree of weathering (alteration or infiltration of iron dioxide in the matrix of $\mathrm{Cb} 3$ and $\mathrm{Cb} 1$-related microfault). The clast-supported structure indicates less brittle fragmentation and less grain comminution, possibly in a more stable seismic regime, as suggested by the subcritical character of the microcracks. $\mathrm{Cb} 3$ is probably the last cataclastic band to form, once it contains fragments of $\mathrm{Cb} 1$.

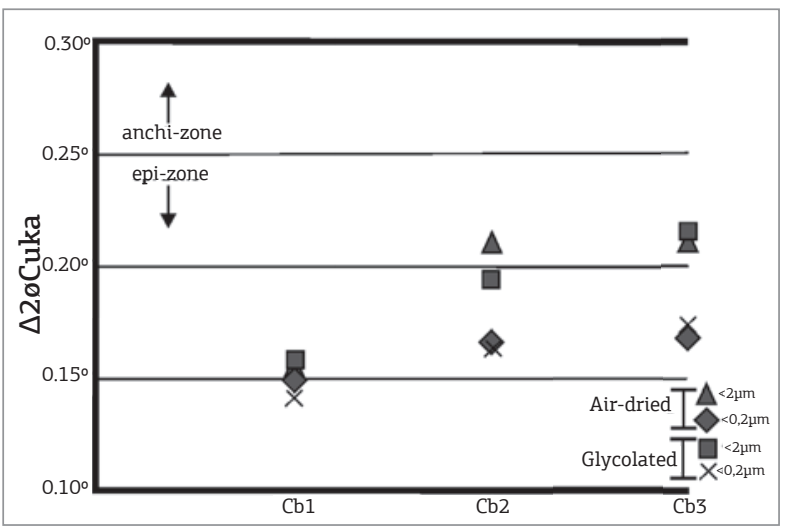

Figure 9. Plot of the Kübler Index measured for the analyzed samples for either air-dried and glycolated experiments. Note that all plot within the epi-zone field and that $\mathrm{Cb} 2$ and $\mathrm{Cb} 3$ show a different behavior when compared to $\mathrm{Cb} 1$ (see text for discussion). 
Besides the above deformation mechanisms taking place during the genesis of these cataclastic rocks, feldspar-to-mica reactions might also have occurred, as suggested by the mineralogical variation between protolith and the cataclastic bands. The influence of hydrothermal fluids in fault rocks rheology has been discussed in the literature (e.g. White \& Knipe 1978; Evans 1980; Imber et al. 1997; Wibberley 1999; Sibson 2000). These fluids might induce feldspar-to-mica reactions that produce micas and quartz in solution. If quartz penetrates and is released through penetrative discontinuities (e.g. metamorphic foliation), then the rock is enriched in micas and is thus weakened. To the contrary, it is silicified and hardened.

Evans (1990) and Wibberley (1999) discuss feldspar-tomica reactions and demonstrate the requirement of an acidic fluid for the reactions to take place, which is not unexpected in a shear zone environment. These reactions take place within a rather narrow range of temperature between $250^{\circ}-400^{\circ} \mathrm{C}$, thus limiting the generation of the cataclastic bands to this range.

As the microstructures present in the cataclastic bands are not penetrative and the cataclastic bands are not continuous, silica in solution must have locally migrated (e.g. through microfaults/microcracks) and precipitated in dilatant sites (e.g. where dilatancy assisted rigid-body rotation took place), thus silicifying $\mathrm{Cb} 1$ and $\mathrm{Cb} 3$.

\section{A few words on fault rock classification}

A brief discussion on the basis of the microtectonic analysis of the CSZ cataclastic rocks concerns their classification. These rocks were first described as cemented breccias (Campanha et al. 1994). The most used classification of fault rocks by Sibson (1977), which is highly based on a previous classification by Higgins (1971), requests two main criteria: random vs. foliated fabric and cohesive or non-cohesive structures. If rocks are non-cohesive, then they are subdivided as fault breccias or fault gouges depending on their visible fragments percentages. In contrast, if they are cohesive and non-glassy, they are either subdivided into the cataclastic series if they have random fabric, or into the mylonitic series if they are foliated.

As presented here, a cataclastic foliation indicates that at least Cb1 maintained its primary cohesion and that the similarity between the bulk composition of the three matrix and the protolith indicate no secondary cementation. It is not the case of $\mathrm{Cb} 3$, where iron dioxide (which could be either external or result of mineral alteration) seems to have infiltrated $\mathrm{Cb} 3$ and $\mathrm{Cb} 1$-related microfaults after silicification. Higgins (1971) pointed out that noncohesive fault rocks are secondarily cemented with external material. In the case of $\mathrm{Cb} 1, \mathrm{Cb} 2$ and $\mathrm{Cb} 3$ they were syntectonically cemented as a result of feldspar-to-mica reactions. The cataclastic foliation of $\mathrm{Cb} 1$ indicates that random-fabric is not specific feature of cataclastic rocks sensu strictu as also pointed out by Chester et al. (1985) and Lin (1999). Thus, the correct classifications of Cb1, $\mathrm{Cb} 2$ and $\mathrm{Cb} 3$, respectively, are: foliated protocataclasite, protocataclasite and crush breccia.

\section{Ages and tectonic correlation}

The CSZ is located within a rather stable cratonic segment of the Gondwana paleocontinent whose western margin underwent orogenesis (Ramos 2003) in the construction of the Gondwanides mobile belt. Even though a few thousands of kilometers away from the orogen, some authors discussed the influence of the orogenesis in the formation of intracratonic sedimentary basins, such as the Paraná Basin (e.g. Milani \& de Wit 2008; Zalán 2004, Ramos 2003; Milani \& Filho 2000; Milani \& Zalán 1999; Milani \& Ramos 1998; Ramos et al. 1986). Mostly the authors discussed a cratonward propagation of regional flexural subsidence caused by the Gondwanides Belt orogenic cycles in the reactivation of NE-SW-trending pre-existent crustal weakness zones (probably inherited from the Brasiliano Orogeny) that comprise the basement of intracratonic basins.

For the Parana basin, which is nearest to the CSZ, two accelerated subsidence events are recorded (Fig. 8), the first being a result of the Precordillera Orogeny and the second of the Chanica Orogeny. It is then suggested here that $\mathrm{Cb} 1$ is a result of a Lower Devonian strike-slip reactivation of the CSZ during the first accelerated subsidence of the Paraná Basin. On the other hand, as previously discussed, $\mathrm{Cb} 2$ and $\mathrm{Cb} 3$ yield two different fraction ages separated for ca. $30 \mathrm{Ma}$, where the $<0.2 \mu \mathrm{m}$-fraction ages $310 \mathrm{Ma}$ and the $<2 \mu \mathrm{m}$-fraction ages $340 \mathrm{Ma}$. The younger ages are more likely to represent a second cataclastic and dip-slip event associated with the onset of the post-Chanica Orogeny subsidence ca. $311 \mathrm{Ma}$. On the other hand, the older ages of the coarser fraction correspond to the middle of the Chanica Orogeny. We propose that the coarser and older fraction represents a mixture of the $310 \mathrm{Ma}$-authigenic illite with inherited illites from the protolith or more likely from the $\mathrm{Cb} 1$. Any correlation of the investigated cataclasites to Cenozoic tectonics events (as suggested by Campanha et al. 1994 and Campanha \& Ens 1996) can be excluded.

\section{CONCLUSION}

The Camburu Shear Zone underwent brittle regime during two different cataclastic events in the Paleozoic. The first event took place ca. $402 \pm 6 \mathrm{Ma}$, during Lower Devonian, producing a foliated protocataclasite. This rock was dominantly deformed by cataclastic flow assisted brittle 
fragmentation with local sigma-like crystals of quartz and syntectonic feldspar-to-mica reactions. The minimum temperature for quartz plasticity is $280 \pm 30^{\circ} \mathrm{C}$ and top temperatures for feldspar-to-mica reactions are $-400^{\circ} \mathrm{C}$. It is, thus, the temperature range of development of the foliated protocataclasite, which agrees with Illite Crystallinity (KI values) that points to high temperatures within the epi-zonal field (lower greenshist facies).

A second cataclastic event took place 310.9 $\pm 8 \mathrm{Ma}$, during Upper Carboniferous, producing protocataclasites and crushed breccias. Deformation was mainly brittle and under relatively low temperature within the epi-zonal field as indicated by KI. As no evidence for plasticity was seen in these fault rocks, the lower temperature should be inferred as that of the minimum for feldspar-to-mica reactions, between $250^{\circ} \mathrm{C}$, and the maximum around $310^{\circ} \mathrm{C}$, which is the highest temperature (considering $\pm 30^{\circ} \mathrm{C}$ of error) for the onset of quartz plasticity.

The temperature ranges for the two cataclastic events indicate a tectonic environment where brittle and ductile deformations overlap, although a seismic regime still prevails. As the older foliated protocataclasite contains critical microcracking, it is inferred that the following cataclastic event was under unstable seismic regime. It is perhaps the reason that the second cataclastic event generated two different cataclastic rocks.

Previous morphotectonic studies indicate that the CSZ separates two plateaus, one downthrown in relation to the other by a normal reactivation of the CSZ with extensional SE-NW-trending $\sigma_{3}$ and associated slickenlines. The observed slickenlines at the interface between the two cataclastic events here presented show a crosscut relation where younger dip-slip slickenlines cut directional ones. Both families of slickenlines are probably related to the Paleozoic evolution of the CSZ associated to its positive-flower structure and greenschist P-T conditions. The older strike-slip activity, during the first cataclastic event, is probably related to final exhumation processes of the fault, whereas the second lower-temperature event could be related to a dip-slip accommodation of blocks within the positive-flower structure.

According to previous studies (e.g. Tassinari et al. 2006), the Coastal Domain reached $450^{\circ} \mathrm{C}$ by $480 \mathrm{Ma}$, following a cooling rate of $3^{\circ} \mathrm{C} / \mathrm{Ma}$. Our data suggest that this rate is too fast, once temperatures would be as low as $210^{\circ} \mathrm{C}$ by $400 \mathrm{Ma}$, which is below epizonal conditions as estimated here for the Lower Devonian cataclastic event ( $400 \mathrm{Ma}$ and up to $\left.400^{\circ} \mathrm{C}\right)$.

These cataclastic events probably resulted from a far-field orogenic effect associated to the cratonward propagation of regional flexural subsidence associated to the Gondwanides Belt in the western margin of Gondwana. Two Paleozoic post-orogenic accelerated subsidence events are recorded in the intracratonic Parana Basin, the first from the Lower to Upper Devonian and a second with onset during the Upper Carboniferous.

\section{ACKNOWLEDGEMENTS}

This research was financially supported by Petrobras in its project named "Faults, Stress Fields and Fluid Flow" coordinated by Prof. Alberto Pio Fiori of the Federal University of Paraná, Brazil.

\section{REFERENCES}

Blenkinsop T. 2000. Deformation Microstructures and Mechanisms in Minerals and Rocks: United States of America, Klumwer Academic Publishers, 150p.

Brodie K., Fettes D., Harte B. 2007. Structural terms including fault rock terms. Online at www.bgs.ac.uk/scmr. Last visited in January 8, 2013.

Brito Neves B.B. \& Cordani U.G. 1991. Tectonic evolution of South America during Late Proterozoic. Precambrian Research, 53:23-40.

Campanha G.A.C., Ens H.H., Poçano W.L. 1994. Análise morfotectônica do Planalto do Juqueriquerê, São Sebastião. Revista Brasileira de Geociências, 24:32-42.

Campanha G.A.C. \& Ens H.H. 1996. Estruturação geológica da região da Serra do Juqueriquerê, São Sebastião, SP. Série Científica, Boletim IGC-USP, 27:41-49.
Chester F.M., Friedman M., Logan J.M. 1985. Foliated cataclasite. Tectonophysics, 111:139-146.

Dias Neto C.M. 2001. Evolução tectono-termal do Complexo Costeiro (Faixa de Dobramentos Ribeira) em São. Paulo. PhD Thesis, University of São Paulo,

Dias Neto C.M., Correia C.T., Munha J.M.U, Tassinari C.C.G. 2008. Litoquímica dos granitóides da estrutura em flor de São Sebastião, São Paulo. Geologia USP, Série Científica, 8:101-114.

Dias Neto C.M., Correia C.T., Tassinari C.C.G, Munha J.M.U. 2009. Os anfibolitos do Complexo Costeiro na região de São Sebastião, SP. Geologia USP. Série Científica, 9:71-87.

Evans J.P. 1990. Textures, deformation mechanisms, and the role of fluids in the cataclastic deformation of granitic rocks. In: Knipe, R.J., Rutter, E.H. (Eds.), Deformation Mechanisms, Rheology and Tectonics. Geological Society, 54, p. 29-39. 
Ferrari A.L. \& Riccomini C. 2003. Análise estrutural das brechas tectônicas silicificadas do Gráben de Guanabara - RJ. In: Boletim de Resumos do $9^{\circ}$ Simpósio nacional de Estudos Tectônicos, Búzios-RJ. Rio de Janeiro, SBG, p.137-139.

Frey M., de Capitani C., Liou J.G. 1991. A new petrogenetic grid for lowgrade metabasites. Journal of Metamorphic Geology, 9:497-509.

Fuhrmann U., Lippolt H.J., Hess J.C. 1987. Examination of some proposed K-Ar standards: ${ }^{40} \mathrm{Ar} /{ }^{39} \mathrm{Ar}$ analyses and conventional K-ArData. Chemical Geology, 66:41-51.

Govindaraju K. 1995. Working values with confidence limits for twenty-six CRPG, ANRT and IWG-GIT geostandards. Geostandards, $\mathrm{XIX}$, special issue.

Haines S.H. \& van der Pluijm B.A. 2008. Clay quantification and ArAr dating of synthetic and natural gouge: Application to the Miocene Mazatán detachment fault, Sonora, Mexico. Journal of Structural Geology, 30(4):525-538.

Heinrichs H. \& Herrmann A.G. 1990. Praktikum der Analytischen Geochemie. - 669 S., Springer Verlag.

Heilbron M. \& Machado N. 2003. Timing of terrain accretion in the Neoproterozoic-Eopaleozoic Ribeira Orogen (SE Brazil). Precambrian Research, 125:87-112

Higgins M.W. 1971. Cataclastic Rocks. In: Professional Paper, United States Geological Survey, 687, 97p

Imber J., Holdsworth R.E., Butler C.A., Lloyd G.E. 1997. Fault zone weakening processes along the reactivated Outer Hebrides Fault Zone, Scotland. Journal of the Geological Society, 154:105-109.

Johnson Q. \& Zhou R.S. 2000. Checking and estimating RIR values. Advances in X-Ray Analysis, 42:287-296.

Löbens S., Bense F.A., Wemmer K., Dunkl I., Costa C.H., Layer P. Siegesmund S. 2010. Exhumation and uplift of the Sierras Pampeanas: preliminary implications from $\mathrm{K}-\mathrm{Ar}$ fault gouge dating and low-T thermochronology in the Sierra de Comechingones (Argentina). International Journal of Earth Science, 100:671-694

Lyons J.B. \& Snellenberg J. 1971. Dating faults. Geological Society of America Bulletin, 82:1749-1752.

Killick A.M. 2003. Fault rock classification: an aid to structural interpretation in mine and exploration geology. South African Journal of Geology, 10:395-402.

Kralik M., Klima M., Riedmüller G. 1987. Dating fault gouges. Nature, 327:315-317.

Kübler B. 1967. La cristallinité de l'illite et les zones tout à fait supérieures du métamorphism. Etages Tectonique, Colloque de Neuchâtel, Neuchâtel.

Kübler, B. 1968. Evaluation quatitativ du métamorphism par la cristallinité de l'illite. Bull. Centre Recherches Pau-SNPA, 2:385-397.

Morais S.M. 1999. Programa Levantamentos Geológicos do Brasil: Integração Geológica da Folha Santos SF.23-Y-D. São Paulo, Brazilian Geological Survey, scale 1:250.000.

Motoki A., Vargas T., Iwanuch W., Sichel S.E., Balmant A., Aires J.R. 2011. Tectonic breccia of the Cabo Frio area, State of Rio de Janeiro, Brazil, intruded by Early-Cretaceous mafic dyke: evidence of the Pan-African brittle tectonism? Revista Escola de Minas, Ouro Preto, 64(1):25-36

Milani E.J. \& Ramos V.A. 1998. Orogenias paleozoicas no domínio sul-ocidental do Gondwana e os ciclos de subsidência da Bacia do Paraná. Revista Brasileira de Geociencias, 28(4):527-544.

Milani E.J. \& Zalán P.V. 1999. An outline of the geology and petroleum systems of the Paleozoic interior basins of South America. Episodes, 22(3):199-205.
Milani E.J. \& Filho, A.T. 2000. Sedimentary basins of South America. In: Cordani U.G., Milani E.J., Filho, A.T., Campos D.A. (Eds.), Tectonic Evolution of South America, Rio de Janeiro, 31 ${ }^{\text {st }}$ International Geological Congress, 389-453.

Milani E.J. \& de Wit M.J. 2008. Correlations between the classic Paraná and Cape-Karoo sequences of South America and southern Africa and their basin infills flanking the Gondwanides: du Toit revisited. In: Pankhurst, R.J., Trouw, R.A.J., Brito Neve, B.B., de Wit, M.J. (Eds.), West Gondwana: Pre-Cenozoic Correlations Across the South Atlantic Region. Geological Society, London, Special Publications, 294, p. 319-342.

Minioli B. 1971. Determinações potássio-argônio em rochas localizadas no litoral norte do Estado de São Paulo. Anais da Academia Brasileira de Ciências, 43(2):443-448.

Passchier C.W. \& Trouw R.A.J. 2005. Microtectonics. Springer-Verlag, Berlin, 366p

Ramos V.A., Jordan T.E., Allmendinger R.W., Mpodozis C., Kay S.M., Cortes J.M., Palma M. 1986. Paleozoic terrains of the central Argentine-Chilean Andes. Tectonics, 5(6):855-880

Ramos V.A. 2003. Paleozoic orogenies in the western margin of Gondwana. In: International Symposium on Tectonics 3, Búzios, p. $111-113$

Scholz C.H. 2002. The mechanics of Earthquakes and Faulting. Cambridge University Press, Cambridge, $2^{\mathrm{a}}$ Ed., 473p.

Schmid S.M. \& Handy M.R. 1991. Towards a genetic classification of fault rocks: geological usage and tectonophysical implications. In: Muller D.W., Mackenzie J.A., Weissert H. (Eds.), Controversies in Modern Geology. Academic Press, London, p. 339-361.

Schumacher E. 1975. Herstellung von $99,9997 \%{ }^{38} \mathrm{Ar}$ für die ${ }^{40} \mathrm{~K} /{ }^{40} \mathrm{Ar}$ Geochronologie. Geochron. Chimia, 24:441-442.

Sibson R.H. 1977. Fault rocks and fault mechanisms. Journal of the Geological Society of London, 133:191-213.

Sibson R.H. 1986. Brecciation processes in fault zones: inferences from earthquakes rupturing. Pure and Applied Geophysics, 124:159-175.

Sibson R.H., 1989. Earthquake faulting as a structural process. Journal of Structural Geology, 11:1-14.

Sibson R.H., 2000. Fluid involvement in normal faulting. Journal of Geodynamics 29:469-499.

Siebel W., Hann H.P., Danisík M., Shang C.K., Berthold C., Rohrmüller J., Wemmer K., Evans N.J. 2009. Age constraints on faulting and fault reactivation - a multi-chronological approach. International Journal of Earth Science, 99(6):1187-1197.

Snoke A.W., Tullis J., Todd V.R. 1998. Fault-related rocks. Princeton University Press, Princeton, 613p.

Spry A. 1969. Metamorphic Textures. Pergamon, London, 350p.

Steiger R.H. \& Jäger E. 1977. Subcommission on geochronology: convention on the use of decay constants in geo- and cosmochronology. Earth Planet. Science Letter, 36:359-362.

Stipp M., Stünitz H., Heilbronner R., Schmid S.M. 2002. The eastern Tonale fault zone: a "natural laboratory" for crystal plastic deformation of quartz over a temperature range from $250^{\circ}$ to $700^{\circ} \mathrm{C}$. Journal of Structural Geology, 24:1861-1884.

Surace I.R., Clauer N., Thélin P., Pfeifer F. 2011. Structural analysis, clay mineralogy and $\mathrm{K}-\mathrm{Ar}$ dating of fault gouges from Centovalli Line (Central Alps) for reconstruction of their activity. Tectonophysics, 510:80-93. 
Tassinari C.C.G. 1988. Idades das rochas e dos eventos metamórficos da porção sudeste do Estado de São Paulo e sua evolução crustal. PhD Thesis, University of São Paulo.

Tassinari C.C.G. \& Campos Neto M.C. 1988. Precambrian continental crust evolution of southeastern São Paulo State: based on isotopic evidences. Geochemica Brasiliensis, 2(2):175-183.

Tassinari C.C.G., Munha J.M.U., Dias Neto C.M., Palacios T., Fonseca P.T. 2006. Constraints on the thermochronological evolution of Ribeira Fold Belt, SE Brazil: Evidence for long-term elevated geothermal gradient of Neoproterozoic Orogenies. In: $\mathrm{V}$ South American Symposium on Isotope Geology, 2006, Punta del Leste. V-SSAGI Short Papers, vol. 1, p. 200-203.

Warr L.N. \& Rice A.H.N. 1994. Interlaboratory standardisation and calibration of clay mineral crystallinity and crystallite size data. Journal of Metamorphic Geology, 12:141-152.

Warr L.N. 1996. Standardized clay mineral crystallinity data from the very low-grade metamorphic facies rocks of south New Zealand. European Journal of Mineralogy, 8,115-127.

Waters A.C. \& Campbell C.D. 1935. Mylonites from the San Andreas fault zone. American Journal of Science, 174:473-503.

Wemmer K. 1991. K-Ar-Altersdatierungsmöglichkeiten für retrograde Deformationsprozesse im spröden und duktilen Bereich - Beispiele aus der KTB-Vorbohrung (Oberpfalz) und dem Bereich der Insubrischen Linie (N-Italien). Göttinger Arb. Geol. Paläont., 51:1-61.

Wibberley C. 1999. Are feldspar-to-mica reactions necessarily reaction-softening processes in fault zones? Journal of Structural Geology, 21:1219-1227.
White S.H. \& Knipe R.J. 1978. Transformation and reaction enhanced ductility in rocks. Journal of the Geological Society of London, 135:513-516.

Wolff R., Dunkl I., Kiesselbach G. Wemmer K., Siegesmund S. 2012. Thermochronological constraints on the multiphase exhumation history of the Ivrea-Verbano Zone of the Southern Alps. Tectonophysics, 579:104-117.

Woodcock N.H. \& Mort K. 2008. Classification of fault breccias and related fault rocks. Geological Magazine, 145(3):435-440

Zalán P.V. 2004. Evolução Fanerozóica das bacias sedimentares brasileiras. In: Matesso-Neto V., Bartoreli A., Carneiro C.D.R., Brito Neves B.B. (Eds.), Geologia do Continente Sul-Americano, Beca, p. 595-615.

Zalán P.V. \& Oliveira J.A.B. 2005. Origem e evolução estrutural do Sistema de Riftes Cenozóicos do Sudeste do Brasil. In: Petrobrás, Rio de Janeiro, Boletim, 13, p. 269-300.

Zwingmann H., Yamada K., Tagami T. 2010a. Timing of brittle deformation within the Nojima fault zone, Japan. Chemical Geology, 275:176-185.

Zwingmann H., Mancktelow N., Antognini M., Lucchini R. 2010b. Dating of shallow faults: New constraints from the Alp Transit tunnel site (Switzerland). Geology, 38:487-490.

Arquivo digital disponível on-line no site www.sbgeo.org.br 